\title{
Comparison of narcissism levels of students in the faculty of sports sciences in terms of some demographic variables
}

\author{
Gul CAVUSOGLU ${ }^{1}$, Ali Kerim YILMAZ ${ }^{1}$, Menderes KABADAYI ${ }^{1}$, \\ Samet Hasan ABACI ${ }^{2}$, M. Yalcin TASMEKTEPLIGIL ${ }^{1}$ \\ Faculty of Yaşar Doğu Sport Sciences, University of Ondokuz Mayıs, Samsun, Turkey. \\ ${ }^{2}$ Department of Biometry and Genetic, University of Ondokuz Mayıs, Faculty of Agriculture, Samsun, Turkey. \\ Address correspondence to A. K. Yilmaz, e-mail:alkrm_ylmz@hotmail.com
}

\begin{abstract}
The purpose of this study is to find out the narcissism levels of the students in Faculty of Sports Sciences and to compare these in terms of some demographic variables. The sample of the study consists of a total of 180 students (66 females, 114 males) studying in three different departments of faculty of sports sciences (Physical Training and Sports Education, Sports Management and Coaching Education) who agreed to participate in the study voluntarily. In the study, Narcissistic Personality Inventory was used as data collection tool. The normality assumption tests of the data were conducted with KolmogorovSmirnov Test. Since the data did not meet the parametric test assumptions, nonparametric tests "Mann-Whitney U" and "Kruskal Wallis" were used in order to find out the differences between personality traits and narcissism. Significant differences were found between age and the sub dimensions of exhibitionism and entitlement, between year of study and entitlement, and between being elite and exhibitionism and exploitativeness ( $\mathrm{p}<0.05)$. In addition, branches and all sub dimensions were compared and no significant difference was found in any of the sub-dimensions ( $p>0.05$ ). No significant difference was also found between total narcissism scores and the variables. As a conclusion, statistically significant difference was found between students' narcissistic personality traits and the variables of age, year of study and being elite. Based on these results, the fact that the students show narcissistic personality traits although they are still students shows that it is necessary to take the necessary steps before these attitudes and perceptions reach harmful extents and continue increasingly in their occupations.
\end{abstract}

Keywords: Narcissism, student, sports sciences.

\section{INTRODUCTION}

Personality means permanent personal characteristics and it is a routine and stabile state that includes an individual's behavioral actions and reactions (14). Personality disorder can be accepted as deviation from "normal personality". In this sense, narcissism can be defined as a personality deviation from the normal. Individuals with narcissistic characteristics use other people in accordance with their purposes, they have an exaggerated sense of value and they expect to be valued just the same by people around. However, despite this expectation, they do not show empathy to people around (5). Narcissistic personality is defined as a person who is has an extreme admiration for his/her own physical and psychological characteristics and a person who likes himself/herself very much $(10,11)$. Although there are various views on the definition of narcissism, there is a great consensus about its behavioral definition. Narcissism includes an intrinsic feeling of pleasure, self-respect and trusting in oneself more than others (9). Basic clinical characteristics of narcissistic personality disorder are grandiosity, extreme self-dependence, indifference and lack of empathy for others despite running after others to get appreciation and approval (13). The foundations of narcissism formation in individuals are laid in babyhood. Emotional conflicts a child experiences with the mother and the negations in families' ways of raising children are stated to cause the development of narcissism (15). Thus, narcissistic traits are seen in a great number of people in different degrees and they have become quite common under today's circumstances. Especially in consumer societies, narcissistic personality disorder is 
significantly higher when compared with cooperative societies (5) and it can be seen in a great number of leaders, businessmen, etc. in our day (17).

Due to their negative experiences with their families in early childhood, narcissist individuals show hostility and skepticism in their future relationships with humans. As a result of this, prerequisites between social feedback and selfinference are somewhat ambiguous and thus, doubts arise about the value of social feedback. Narcissist individuals feel the need to question whether others have appreciative thoughts for them and thus keep their relations under pressure to get the feedback they desire. However, due to their negative experiences in their early childhood, they do not only feel insecure, they also do not care about whether they love other people and at the same time, they despise other people (9).

Generally without realizing, narcissist individuals use other people for their own interests, they exploit them and expect them to fulfill their wishes without giving much in return. Thus, they are considered as extremely egocentric people who are ungiven and who are away from being modest (12). Self-esteem of narcissist individuals is fuelled by interests, likes and approvals from outside. These people cannot stand criticism and they always expect praise. Thus, their appearances and behaviors are always shaped to attain these. Since they use others to aggrandize and to see and show themselves superior, their friendships are based on deriving personal benefit in this direction. Since narcissistic people cannot show empathy to others' feelings, thoughts and needs, they are known as selfish and egocentric in their relationships (16).

Narcissism can affect individuals' (athletes) performance positively or negatively. Narcissist athletes' feeling valuable depends on their skills of being able to show their superiority to others and gaining their admiration. They show their best moves in sports fields and try to show their superiority and attract the attention on themselves. They care about being loved and cared less than other people. Thus, in order to prevent their self-esteem from falling to pieces due to failure in performance, they act more challenging and persistent during competitions. The only important thing for narcissist athletes is to win. They can also resort to non-moral behaviors to attain their goals $(21,20)$. However, in pathological narcissism, most of the time an athlete is jealous of other athletes and believes that other athletes are jealous of him/her, too. Conscious or unconscious jealousy is on the forefront in narcissist athletes. Other people's success causes uneasiness because it triggers their feelings of insufficiency. All these behaviors can affect an athlete's performance negatively in individual sports. In team sports, this situation can turn into something that harms the feeling of unity and solidarity and it can cause an obstacle against a team's heading for the goal collectively. With this aspect, it seems important for individuals to have acceptable levels of narcissism. Based on this, the purpose of this study is to determine the narcissism levels of the students in the Faculty of Sports Sciences and to compare these in terms of some demographic variables.

\section{MATERIALS \& METHODS}

\section{Sample of the Research}

The sample of this study consists of a total of 180 students (66 females, 114 males) studying in three different departments of Ondokuz Mayıs University Faculty of Sports Sciences (Physical Training and Sports Education=50, Sports Management=98 and Coaching Education=32) who agreed to participate in the study voluntarily.

\section{Data Collection Tool}

In the study, Narcissistic Personality Inventory developed by Ames et al. (1), which had 16 questions, was used as data collection tool (1). The Turkish form of the inventory (NPI) was made by Atay in 2009 (2). In the first study conducted by Atay following the pilot application, Cronbach's Alpha value of the inventory was found as 0.57 . Since the reliability coefficient was below the expected values, the correlation of each factor with the inventory was checked and four items which were found to be perceived negatively and which did not contribute to the inventory were revised. In the measurements conducted right after this change, Cronbach's Alpha value rose up to 0.652 . Cronbach's Alpha value of the present study is 0.60. Like the English form of the inventory, the questions in the 16-question-inventory have six factors in the Turkish version as "exhibitionism", "superiority", "authority", "entitlement", "self-sufficiency" and "exploitativeness" (2). These 6 factors, which are the subscales of Narcissism, represent the following:

Superiority: Represents self-confidence, independence, being assertive and need for success.

Exploitativeness: Represents behaviors that include rebelliousness, lack of harmony and not showing respect and tolerance to others. 
Authority: Reflects dominance, being assertive, leadership, criticism and self-confidence.

Entitlement: Contains behaviors that include being ambitious, need for success, dominance, hostility, rudeness and obstinacy.

Self-sufficiency: Means the need for assertiveness, independence, self-confidence and success.

Exhibitionism: Is associated with flatulency, seeking sensation, search for feelings, being extravert and not being able to control impulses (9).

The scores one can get from narcissism inventory for each factor are as follows: authority 02, exhibitionism 0-3, exploitativeness 0-3, entitlement $0-2$, self-sufficiency $0-3$, superiority $0-3$ and the total score is between 0-16 (total narcissism). As the score increases, the levels of narcissism also increase (3).

\section{Data Analysis}

SPSS 21 software was used for the analysis of the data obtained. The normality assumption tests of the data were conducted with Kolmogorov-Smirnov Test and the data were not found to have a normal distribution $(\mathrm{P}<0.05)$. For data collection tool, the data were analyzed with descriptive statistics and to determine the difference between demographic variables and narcissism, Mann-Whitney $U$ test was used for groups of two, while Kruskal Wallis H test was used for the comparison of groups of more than two. Mann Whitney U test was used to find out the differences between groups.

\section{RESULTS}

According to Table 1, significant difference was found between the sub-dimensions of age and exhibitionism and entitlement $(p<0.05)$. It is understood that the difference in the sub dimension of exhibition results from the age groups of 24 and older and the age group between 18 and 20; while the difference in the sub-dimension of entitlement results from the age groups of 21 and 23 and from the age group of 24 and older.

Table 1. Comparison of levels of narcissism in terms of the variable of age.

\begin{tabular}{lcccccccc}
\hline Age & $\mathrm{n}$ & Mean & $\mathrm{SD}$ & Median & Min & Max & $\mathrm{IQR}^{*}$ & $\mathrm{P}$ \\
\hline Exhibitionism & & & & & & & & \\
$18-20$ & 55 & $0.73^{\mathrm{b}}$ & 1.04 & 0.00 & 0.00 & 3.00 & 1.00 & \\
$21-23$ & 94 & $1.08^{\mathrm{a}}$ & 1.02 & 1.00 & 0.00 & 3.00 & 2.00 & 0.036 \\
$24+$ & 31 & $1.13^{\mathrm{a}}$ & 0.99 & 1.00 & 0.00 & 3.00 & 2.00 & \\
Entitlement & & & & & & & & \\
$18-20$ & 55 & $0.74^{\mathrm{ab}}$ & 0.75 & 1.00 & 0.00 & 2.00 & 1.00 & \\
$21-23$ & 94 & $0.81^{\mathrm{a}}$ & 0.72 & 1.00 & 0.00 & 2.00 & 1.00 & 0.045 \\
$24+$ & 31 & $0.45^{\mathrm{b}}$ & 0.67 & 0.00 & 0.00 & 2.00 & 1.00 & \\
\hline
\end{tabular}

$\mathrm{a}, \mathrm{b}$ : The differences between the group means with different letters in the same column are significant.

*: The difference between the third quarter and the first quarter in the research group.

Table 2. Comparison of narcissism levels in terms of the variable of year of study.

\begin{tabular}{ccccccccc}
\hline \multirow{2}{*}{ Year } & \multicolumn{7}{c}{ Entitlement } & \multirow{2}{c}{$\mathrm{P}$} \\
\cline { 2 - 6 } & $\mathrm{n}$ & Mean & $\mathrm{SD}$ & Median & Min & Max & $\mathrm{IQR}^{*}$ & \\
\hline 1 & 7 & $1.71^{\mathrm{a}}$ & 0.49 & 2.00 & 1.00 & 2.00 & 1.00 & \\
2 & 54 & $0.78^{\mathrm{b}}$ & 0.72 & 1.00 & 0.00 & 2.00 & 1.00 & \\
3 & 67 & $0.60^{\mathrm{b}}$ & 0.63 & 1.00 & 0.00 & 2.00 & 1.00 & 0.004 \\
4 & 52 & $0.71^{\mathrm{b}}$ & 0.80 & 0.50 & 0.00 & 2.00 & 1.00 & \\
\hline
\end{tabular}

$a, b$ : The differences between the group means with different letters in the same column are significant.

*The difference between the third quarter and the first quarter in the research group. 
Table 3. Comparison of narcissism levels in terms of the variable of being elite.

\begin{tabular}{|c|c|c|c|c|c|c|c|c|c|c|c|c|c|c|}
\hline \multirow{2}{*}{$\begin{array}{l}\text { Being } \\
\text { elite }\end{array}$} & \multicolumn{7}{|c|}{ Exhibitionism } & \multicolumn{7}{|c|}{ Exploitativeness } \\
\hline & $\mathrm{n}$ & Mean & $\mathrm{SD}$ & Median & Min & Max & $\mathrm{IQR}^{*}$ & $\mathrm{n}$ & Mean & $\mathrm{SD}$ & Median & Min & Max & $\mathrm{IQR}^{*}$ \\
\hline Yes & 48 & 1.29 & 1.07 & 1.00 & 0.00 & 3.00 & 2.00 & 48 & 1.23 & 0.90 & 1.00 & 0.00 & 3.00 & 1.00 \\
\hline No & 132 & 0.87 & 1.00 & 1.00 & 0.00 & 3.00 & 2.00 & 132 & 1.57 & 0.90 & 2.00 & 0.00 & 3.00 & 2.00 \\
\hline$P$ & & & & 0.013 & & & & & & & 0.016 & & & \\
\hline
\end{tabular}

* The difference between the third quarter and the first quarter in the research group.

Table 4. Comparison of narcissism levels in terms of the variable of branch.

\begin{tabular}{|c|c|c|c|c|c|c|c|c|c|c|c|c|c|}
\hline \multirow{2}{*}{ Sub-Dimensions } & \multicolumn{6}{|c|}{ Individual Sports ( $\mathrm{n}=97)$} & \multicolumn{6}{|c|}{ Team Sports (n=83) } & \multirow{2}{*}{$\mathrm{p}$} \\
\hline & Mean & SD & Median & Min & Max & $\mathrm{IQR}^{*}$ & Mean & SD & Median & Min & Max & $\mathrm{IQR}^{*}$ & \\
\hline Superiority & 1.40 & 0.88 & 1.00 & 0.00 & 3.00 & 1.00 & 1.38 & 0.97 & 1.00 & 0.00 & 3.00 & 1.00 & 0.911 \\
\hline Exhibitionism & 1.01 & 0.98 & 1.00 & 0.00 & 3.00 & 2.00 & 0.95 & 1.09 & 1.00 & 0.00 & 3.00 & 2.00 & 0.483 \\
\hline Authority & 0.93 & 0.75 & 1.00 & 0.00 & 2.00 & 1.50 & 1.00 & 0.78 & 1.00 & 0.00 & 2.00 & 2.00 & 0.534 \\
\hline Exploitativeness & 1.36 & 0.89 & 1.00 & 0.00 & 3.00 & 1.00 & 1.61 & 0.92 & 2.00 & 0.00 & 3.00 & 1.00 & 0.069 \\
\hline Entitlement & 0.72 & 0.76 & 1.00 & 0.00 & 2.00 & 1.00 & 0.73 & 0.70 & 1.00 & 0.00 & 2.00 & 1.00 & 0.781 \\
\hline Self-sufficiency & 1.66 & 0.93 & 2.00 & 0.00 & 3.00 & 1.00 & 1.72 & 0.93 & 2.00 & 0.00 & 3.00 & 1.00 & 0.616 \\
\hline
\end{tabular}

* The difference between the third quarter and the first quarter in the research group.

Table 5. Comparison of total narcissism scores.

\begin{tabular}{llcccccccc}
\hline Variables & & $\mathrm{n}$ & Mean & $\mathrm{SD}$ & Median & Min & Max & IQR & $\mathrm{p}$ \\
\hline Age & $18-20$ & 55 & 6.64 & 3.31 & 6.00 & 1.00 & 15.00 & 5.00 & 0.057 \\
& $21-23$ & 94 & 7.61 & 2.60 & 8.00 & 1.00 & 13.00 & 3.00 & \\
Year & $23+$ & 31 & 7.13 & 2.97 & 7.00 & 1.00 & 13.00 & 4.00 & \\
& 1 & 7 & 8.86 & 3.48 & 10.00 & 4.00 & 12.00 & 7.00 & 0.231 \\
& 2 & 54 & 6.80 & 2.86 & 7.00 & 1.00 & 15.00 & 3.00 & \\
Being elite & Yes & 48 & 7.52 & 2.90 & 7.00 & 1.00 & 13.00 & 3.00 & 0.459 \\
& 4 & 52 & 7.23 & 2.87 & 7.00 & 1.00 & 13.00 & 3.00 & \\
Branch & No & 132 & 7.13 & 2.92 & 7.00 & 1.00 & 15.00 & 4.00 & \\
& Individual & 97 & 7.08 & 2.71 & 7.00 & 1.00 & 12.00 & 4.00 & 0.486 \\
& Team & 83 & 7.41 & 3.14 & 8.00 & 1.00 & 15.00 & 4.00 & \\
\hline
\end{tabular}

* The difference between the third quarter and the first quarter in the research group.

Significant difference was found between year of study and the sub-dimension of entitlement in Table $2(p<0.05)$. The difference was found to be between students in their first year and students in their second, third and fourth year.

Significant difference was found between being elite and the sub-dimensions of exhibitionism and exploitativeness according to Table $3(\mathrm{p}<0.05)$. In the sub-dimension of exhibitionism, elite athletes were found to have higher narcissism levels, while nonelite athletes were found to have higher narcissism levels in the sub-dimension of exploitativeness.

In Table 4, branch and all sub-dimensions were compared and no significant difference was found in any of the sub-dimensions ( $p>0.05)$.

Age, year, national player status and branch variables were compared for total narcissism scores; 
however, no significant difference was found ( $p>0.05$; Table 5).

\section{DISCUSSION}

The results of this study, which compared the narcissism levels of students being educated in sports, were interpreted as follows.

In this study, significant difference was found between age and the sub-dimensions of exhibitionism and entitlement $(\mathrm{p}<0.05)$. In the subdimension of exhibitionism, the students in the age group of 24 and older were found to have higher narcissism scores than those in the age groups of 1820 and 21-23; while in the sub-dimension of entitlement, students in the age group of 21-23 were found to have higher narcissism scores than those in the age group of 24 and older. Based on these data, the fact that the students in the age group of 24 and older had higher narcissism scores than the other students in the sample group in the sub-dimension of exhibitionism can be due to the experiences of the students in this group about search for emotions, extroversion and not being able to control impulses. In terms of students who got high scores in the subdimension of entitlement, it can be said that these students are more ambitious than the students in other age groups, they are not tolerant to people, they need power more and they are very stubborn. That is, while there is increase in the sub-dimension of exhibitionism with increasing age, a decrease is seen in the scores of the sub-dimension of entitlement. In a way, it can be said that there is an increase in search for feelings and a decrease in behaviors of dominance, hostility, rudeness and stubbornness in the age group of 24 and older. No studies have been found in literature which has found significant difference between age and narcissism. However, in their study, Tazegül \& Soykan (19) stated that narcissism scores of athletes with a sports age of more than 8 years were found to be higher than those of athletes with a sports age of less than 8 years. Ferah \& Tazegül (19) also found that narcissism scores of female athletes with a sports age of more than 10 years were found to be higher than those of athletes with a sports age of between 1-6 and 7-9 (8). However, there are also studies in literature which show that narcissism does not differ in terms of demographic variables such as age, gender, family status, etc (2).

Narcissistic people have the feeling that they are entitled. They have the expectations that they will be given a therapy in which they are favored or they have the tendency to adapt to such expectations. Since they feel invaluable waiting in queues and not being treated special while some people are having their things done more easily, they expect an attitude and treatment in which they will be favored. They strive for being treated special or privileged, and when their expectations are not met, they get furious or humiliate the people who do not treat them special (18). Significant difference was found between the year of study and the sub-dimension of entitlement $(p<0.05)$. The highest level of narcissism was found in students in their first year in terms of the subdimension of entitlement. When students start university, it can be said that a great number of factors are effective in their tendencies of narcissist personality traits becoming more evident. Some of these factors are feeling like one of the rare people who achieve extremely difficult goals, believing that they have the right to ask anything from other people after this point, feeling that they have the necessary equipment and do not need the advice, love or friendship of anybody and thinking that everyone else will need them from now on. An interesting result was the lowest narcissism scores being found in students in their third year of study. It is possible to interpret this result in different ways. For example, it can be interpreted as a coincidence. From another point of view, it can be interpreted that narcissistic personality trait tendencies, which are stronger in the first year of study, can have decreased as a result of students' exhaustion and frustration in the middle of their education life. Cihangiroğlu et al. (2015) found that levels of narcissism differed statistically significantly in terms of the year of study $(p=0.017)$ and that this difference occurred because of the difference between students in their first and fourth year of study and students in their fourth and fifth year of study (4).

Significant differences were found between being elite and the sub-dimensions of exhibitionism and exploitativeness $(p<0.05)$. Elite athletes were found to have higher levels of narcissism in the subdimension of exhibitionism, while non- athletes were found to have higher levels of narcissism in the subdimension of exploitativeness. High levels of narcissism in the sub-dimension of exhibitionism in elite athletes can be explained with the fact that they like their own physical and psychological characteristics and their wish to be praised and to be on the forefront all the time within society. Ferah and Tazegül (2016) stated that narcissistic athletes always tend to be on the forefront and show themselves by proving their abilities (8). In addition, in 1984, 
Emmons stated that narcissistic people placed extreme importance on their physical appearance and that they were extremely motivated when they had a beautiful appearance (6). Narcissistic people use their interpersonal relationships for their own benefits; they use the weak sides of other people to reach their own goals. They use people they have relations with for their own needs and purposes, especially by making them behave in a way that will make them happy. If the people they are related with start not to meet their needs or if they no longer need these people, they get away from these people and find others (18). The fact that non-elite athletes have higher narcissism scores in the sub-dimension of exploitativeness means that they are egocentric and incompatible in their interpersonal relations, they are not tolerant to others, they are introvert and they exploit other people. According to these results, it can be said that non-elite athletes are more adaptive to people and events and they have less tolerance.

In group works, narcissistic people have an exaggerated understanding about their contribution to the group and they ignore other people's positive contributions. They do not take any negative feedback personally or they become furious and lay the blame on the other people in the group (7). Thus, athletes with narcissism personality are more successful in individual sports rather than team sports. A great number of definitions of narcissism say that narcissistic people cannot be good team players. Since they lack the skill of empathy, they do not understand or care about the feelings and thoughts of their team mates, and they consider their team mates as a tool to show their performance. For narcissistic athletes, the important things is not the victory of the team, but being the center of attention by showing their abilities (21). However, no significant difference was found between branch and the sub-dimensions of the scale ( $p>0.05)$.

When the results are assessed in general statistically significant difference was found between students' narcissistic personality traits and age, year of study and being elite. Based on these results, the fact that the students show narcissistic personality traits although they are still students shows that it is necessary to take the necessary steps before these attitudes and perceptions reach harmful extents and continue increasingly in their occupations. In order to do this, it is thought that it will be suitable to include theoretical and practical applications to encourage listening and empathy, to teach them to how to love, how to listen and how to be empathic and to continue this application starting from the first year of study.

\section{REFERENCES}

1. Ames DR, Rose P, Anderson CP. The NPI-16 as a Short Measure of Narcissism. Journal of Research in Personality, 2006; 40:440-450.

2. Atay S. The standardization of narcissistic personality inventory into Turkish. Gazi University J Journal of Economics and Administrative Sciences, 2009; 11(1): 181-196.

3. Atay S. Çalışan Narsist. 1. Baskı, Namar yayınları, İstanbul, 2010.

4. Cihangiroğlu N, Teke A, Uzuntarla Y, Uğrak U. Narsist Kişilik Eğilimleri İle Kumsal Bağlllık Düzeyleri Arasındaki İlişkinin Analizi. Yönetim ve Ekonomi Araştırmaları Dergisi, 2015; 13(1): 1-18.

5. Doğaner İ. Narsisistik Kişilik Bozukluğu, Ege Psikiyatri Sürekli Yayınları, 1996; 1(3).

6. Emmons RA. Factor analysis and construct validity of the Narcissistic Personality Inventory. Journal of Personality Assessment, 1984; 48(3): 291-300.

7. Erbahar A, Dicle Gençer A. İlişkilerde Narsizm. Pdb Kişisel Gelişim Yazıları - Bahar, 2014.

8. Ferah M, Tazegül Ü. Bayan Sporcuların Narsiszm Düzeyini Spor Yaşı Değişkenine Göre Karşılaştırılması. Akademik Sosyal Araştırmalar Dergisi, 2016; 4(33): 436-443.

9. Gülmez N. Narsistik Liderlik Marmara Üniversitesi Sosyal Bilimler Enstitüsü, Yayınlanmış Yüksek lisans tezi, İstanbul, 2009

10. Güney S. Davranış Bilimleri ve Yönetim Psikolojisi Terimler Sözlüğü, Ankara, 1998.

11. Hançerlioğlu O. Ruhbilim Sözlüğü, 2. Baskı, Remzi Kitapevi, İstanbul, 1993.

12. Köroğlu E, Bayraktar S. Kişilik Bozuklukları, 1. Basım, HYB Basım Yayın, Ankara, 2007.

13. Masterson JF. The narcissistic and borderline disorders, an integrated developmental approach, Psikoterapi Enstitüsü Eğitim Yayınları, 2014.

14. Özçetin A, Maraş A, Ataoğlu A, İçmeli C. Deprem Sonucu Gelişen Travma Sonrası Stres Bozukluğu İle Kişilik Bozuklukları Arasında İlişki. Düzce Tıp Fakültesi Dergisi, 2008

15. Özel İ. Dindarlarda narsizm, Uluslararası Sosyal Araştırmalar Dergisi, 2014; (7)32: 310-327.

16. Öztürk O. Ruh Sağlı̆ğ ve Bozuklukları, 9. Baskı, Feryal Matbaası, Ankara, 2002.

17. Sayar K. Benlik; o yakın soru, o uzak ülke. Bilge Adam, 2003; (1): 11-17.

18. Şahin D. Kişilik Bozuklukları. Klinik Gelişim Dergisi. Aralık. 2009; (4): 45-55.

19. Tazegül Ü, Soykan A. The Comparision of Narcissism Levels of Theathletes at Individual Sports According to Their SocioDemographic Features, American International Journal of Contemporary Research, 2013; 3(7): 128-133. 
20. Twenge JM, Campbell KW. Asrın Vebası Narsisizm İlleti 1.Basım, (Çev: Ö. Korkmaz) Kanküs yayınları, İstanbul, 2010.
21. Wallace HM, Baumeister RF. The performance of narcissists rises and falls with perceived opportunity for glory, Journal of Personality and Social Psychology, 2002; 82(5): 819-834. 